\title{
Author Correction: Leptin receptor-expressing neuron Sh2b1 supports sympathetic nervous system and protects against obesity and metabolic disease
}

Lin Jiang, Haoran Su, Xiaoyin Wu, Hong Shen (D), Min-Hyun Kim, Yuan Li, Martin G. Myers Jr (D), Chung Owyang \& Liangyou Rui $\mathbb{D}$

Correction to: Nature Communications https://doi.org/10.1038/s41467-020-15328-3, published online 23 March 2020.

The original version of this Article contained an error in Fig. 2b, in which error bars were missing. This has been corrected in both the PDF and HTML versions of the Article.

Published online: 15 October 2020

\begin{abstract}
(c) (i) Open Access This article is licensed under a Creative Commons Attribution 4.0 International License, which permits use, sharing, adaptation, distribution and reproduction in any medium or format, as long as you give appropriate credit to the original author(s) and the source, provide a link to the Creative Commons license, and indicate if changes were made. The images or other third party material in this article are included in the article's Creative Commons license, unless indicated otherwise in a credit line to the material. If material is not included in the article's Creative Commons license and your intended use is not permitted by statutory regulation or exceeds the permitted use, you will need to obtain permission directly from the copyright holder. To view a copy of this license, visit http://creativecommons.org/licenses/by/4.0/.
\end{abstract}

(c) The Author(s) 2020 